\title{
Pendampingan Peran Keluarga Terhadap Tumbuh Kembang Anak Pada Masa Pandemi Covid-19 Di RA Al Hilal Pamolokan
}

\author{
Emdat Suprayitno ${ }^{1}$, Zakiyah Yasin ${ }^{2 *}$ \\ ${ }^{1,2}$ Fakultas Ilmu Kesehatan Universitas Wiraraja \\ *Email: zakiyafik@wiraraja.ac.id
}

\begin{abstract}
Background: The main environment for children is the family. The child's personality can be supported through the main role of the family. the family also has a role in monitoring and providing supervision of children's growth and development, so that if this role is inadequate then the child's growth and development will not be monitored properly and disturbances that can occur cannot be identified and overcome early on. COVID-19, of course, requires the role of the family to fulfill health needs, fulfill adequate nutrition, and provide proper care. Methods: The assistance provided by the researcher is providing counseling and practice on evaluating the stimulation practices that have been carried out, providing feedbacks, and teaching stimulation practices for those aged above. Stimulation of Early Intervention Detection of Child Development is an activity to stimulate the basic abilities of children aged 0-6 years so that children grow and develop optimally, as well as to find deviations early to make intervention easier. Results: Through PKM activities, children's growth and development, the worst conditions of child growth deviations such as malnutrition can be prevented, because before a child falls into a condition of malnutrition, growth deviations that occur in children can be detected through PKM activities. Conclusion: Addition to preventing growth irregularities, this activity also prevents developmental deviations and mental-emotional deviations during the Covid-19 pandemic.
\end{abstract}

Keywords: covid-19; family; growth and development

\section{PENDAHULUAN}

Covid 19 merupakan virus yang menggoncangkan dunia, begitu juga di Indonesia, ribuan masyarakat Indonesia terinfeksi dan ribuan pula yang meninggal dunia (Suprayitno et al., 2020). Di Sumenep sendiri pemerintah telah memberikan himbauanhimbauan dalam mengatasi wabah ini supaya berjalan efektif dan efisian dalam menanggulagi pandemi covid 19. Dari memakai masker, mencuci tangan hinnga menjaga jarak dan menghindari kerumunan. Selain itu pemerintah juga menghimbau untuk selalu menjaga imun tubuh (Supinganto et al., 2021).

Menjaga imun tubuh sangatlah penting supaya virus-virus tidak mudah masuk ke tubuh manusia Gangguan"pertumbuhan dan perkembangan"merupakan masalah yang serius dan masih belum teratasi (Puspitasari et al., 2021). Kurangnya peran keluarga merupakan salah satu penyebab terjadinya gangguan tumbuh kembang karena keluarga memiliki fungsi penting dalam proses tumbuh kembang anak (Sugeng et al., 2019). Selain itu keluarga juga memiliki peran dalam memantau dan memberikan pengawasan terhadap tumbuh kembang anak, sehingga jika peran tersebut tidak memadai maka tumbuh kembang anak tidak akan terpantau dengan baik dan gangguan yang bisa terjadi tidak dapat diketahui dan diatasi sejak dini. Untuk meminimalisir gangguan tumbuh kembang anak di masa pandemi Covid 19, tentunya memerlukan peran keluarga untuk pemenuhan kebutuhan kesehatan, pemenuhan gizi yang cukup, dan pengasuhan yang tepat (Ulfa, 2020).

Peran keluarga sangat dibutuhkan di masa ini sebab anak tidak mungkin dapat berkembang tanpa bantuan orang lain dan kehidupan anak bisa berlangsung. Meskipun anak-anak tampaknya kurang rentan terhadap Covid-19, efek samping dari pandemi ini 
bisa sangat mengganggu proses perkembangan. Anak-anak mengalami gangguan rutin yang drastis karena penutupan sekolah dan tidak adanya kegiatan di luar ruangan, mereka mungkin tidak sepenuhnya terisolasi (Fatoni et al., 2021).

Dalam kebanyakan kasus, orang tua berada di rumah Dalam hal ini, beberapa anak mungkin belum tentu mengalami perasaan kesepian yang nyata, karena mereka dapat mengimbanginya dengan menghabiskan lebih banyak waktu dengan anggota keluarga mereka dan juga meningkatkan waktu yang dihabiskan dengan media sosial dan internet (de Figueiredo et al., 2021). Tujuan PKM ini adalah meminimalisir gangguan tumbuh kembang anak di masa pandemi covid 19 melalui pendampingan keluarga. kegiatan dalam PKM ini adalah mendampingi keluarga untuk meningkatkan pengetahuan tentang tunbuh kembang anak dan pencegahan Covid-19 sehingga dapat meminimalisir gangguan tumbuh kembang anak di masa pandemi Covid 19.

\section{TINJAUAN PUSTAKA}

Masa kanak-kanak adalah salah satu tahap terpenting dalam kehidupan setiap orang. Memang, sejak usia dini, anak menjadi atau menjadi peka terhadap berbagai rangsangan yang datang dari luar. Oleh karena itu, sangat penting untuk merangsang atau merangsang anak sejak dini untuk meningkatkan aspek-aspek tertentu dari perkembangannya (Hermoyo, 2015). Menurut Pedoman Pembinaan Tumbuh Kembang (CUPW) 2014 Kementerian Pendidikan dan Kebudayaan (Permendicbud) 2014 Pedoman 137, enam aspek perkembangan anak usia dini ditingkatkan Aspek perkembangan tersebut meliputi aspek agama, moral, fisik, indera, kognitif, bahasa, sosial, emosional dan nilai seni.

Menurut Piaget, masa bayi adalah sensasi praoperasi. Selama periode ini, anak mampu mengembangkan praktik pengelolaan lingkungan yang tepat dan sistematis serta mulai memahami simbol yang digunakan untuk objek tertentu (Kurniyati et al., 2021). Menurut Piaget, dalam perkembangan seorang anak terdapat proses herediter yang menjadi dasar mekanisme biologis perkembangan neuromorfik. Seiring bertambahnya usia, sistem saraf Anda menjadi lebih lengkap dan keterampilan Anda meningkat. Sebagai orang dewasa, mereka mengalami adaptasi biologis terhadap lingkungan mereka, menghasilkan perubahan kualitatif dalam struktur kognitif mereka (Permatasari \& Suprayitno, 2020).

Piaget sendiri tidak mempertimbangkan perkembangan kognitif secara kuantitatif. Dengan demikian, Piaget sampai pada kesimpulan bahwa dengan bertambahnya usia, setiap anak tumbuh secara berbeda sesuai dengan kekuatan mental perkembangan kualitatifnya (Lefa, 2014). Orang tua dan orang-orang yang terdekat dengan anak dapat mempengaruhi tumbuh kembang anak. Keluarga erat kaitannya dengan anak dibandingkan dengan masyarakat di lingkungan (Ulfa, 2020).

Dikatakan bahwa keluarga dapat membentuk karakter anak dengan caranya sendiri, dan membantu pertumbuhan dan perkembangan anak dengan membentuk karakter orang dewasa sehingga anak dapat memiliki kebebasan berbicara, kesejahteraan sosial dan kesuksesan dan pemenuhan diri. Pada masa kanak-kanak, proses perubahan perilaku dari kecil menjadi dewasa, proses ketaatan berubah dari individu yang lebih sederhana menjadi individu yang lebih memuaskan dan mandiri. Sebagai orang tua dan guru, mereka memiliki peran paling penting dalam mendukung pertumbuhan dan perkembangan anak-anaknya (Emdat Suprayitno \& Wahid, 2019). 


\section{DESAIN PENELITIAN}

Rangkaian kegiatan yang direncanakan untuk Program Pengabdian yaitu melakukan Survei awal lapangan di RA Al-Hilal Pamolokan menggunakan kuesioner pengetahuan tentang tumbuh kembang anak selama masa pandemic Covid-19 dan pencegahan penularan dengan penerapan protokol kesehatan. Kemudian mengajukan Perizinan kepada mitra untuk melakukan kegiatan pendampingan yang dilakukan selama 2 kali yaitu memberikan penyuluhan tentang tumbuh kembang anak dan cara pencegahan penularan Covid-19. Kegiatan pendampingan dilakukan secara tatap muka yaitu menggunakan metode wawancara, penyuluhan dan tanya jawab.

Media yang digunakan dalam kegiatan ini yaitu leaflet dan materi PPT tentang tumbuh kembang anak dan pencegahan Covdi-19. Kemudian peserta di evaluasi secara lisan dan menggunakan kuesioner tumbuh kembang anak dan pencegahan Covid-19.

\section{HASIL PENELITIAN}

Hasil kegiatan pendampingan diikuti oleh 15 orang keluarga dimana berdasarkan kegiatan yang telah dilakukan terdapat beberapa hasil evaluasi yaitu:

Tabel 1. Hasil evaluasi pendampingan

\begin{tabular}{cccc}
\hline Variabel & Kegiatan & Mean & Pvalue \\
\hline Pengetahuan Tumbuh Kembang Anak & Pre & 6,33 & \multirow{2}{*}{0,001} \\
& Post & 8,07 & \\
Pengetahuan Pencegahan Covid-19 & Pre & 4,45 & 0 \\
& Post & 6,18 & 0,001 \\
\hline
\end{tabular}

Berdasarkan tabel diatas, dapat diketahui bahwa pengetahuan peserta sebelum dan sesudah dilakukan pendampingan, mengalami peningkatan nilai mean dan Nilai uji Wilcoxon di dapatkan Pvalue pengetahuan tumbuh kembang anak=0,001 dan pengetahuan pencegahan Covid-19 Pvalue=0,0001. Hasil ini menunjukkan terdapat perbedaan pengetahuan sebelum dan sesudah pemberian pendampingan peran keluarga dalam perkembangan anak. Pelaksanaan kegiatan pendampingan aktif di ikuti peserta, kerja sama yang baik dan kooperatif dengan kepala sekolah yaitu menyiapkan setting tempat pengabdian dengan protokol kesehatan.

Peserta kegiatan dapat mengerti tentang pentingnya tumbuh kembang anak di masa pandemi covid 19 dibuktikan dengan para peserta terbiasa dan dapat menjalankan $3 \mathrm{M}$ untuk meminimalisir resiko penularan virus corona dan bisa menjaga tumbuh kembang anak dengan memberikan makanan yang bergizi dan seimbang.

\section{PEMBAHASAN}

Berdasarkan hasil uji Wilcoxon di dapatkan Pvalue yaitu 0,001 yang mennujukkan terdapat perbedaan pengetahuan tumbiuh kembang anak dan pencegahan Covid-19 sebelum dan setelah kegiatan pendampingan tumbuh kembang anak selama masa pandemic Covid-19. Penelitian Purwandari (2011) yaitu dengan media modul dan video mampu meningkatkan pengetahuan dan ketrampilan keluarga dalam menstimulasi tumbuh kembang (Suryanto et al., 2014). Menurut Croesnoe (2009), menemukan pemberian stimulasi kognitif di rumah dan taman kanak-kanak berdampak baik dengan orang tua yang memiliki pendapatan rendah (Tatminingsih, 2019).

Keluarga mempunyai kedudukan tertinggi dalam perkembangan anak dan sangat penting karena lingkungan keluarga merupakan tumpuan pertama perkembangan anak 
(Emdat Suprayitno \& Huzaimah, 2020). Dalam perkembangan bayi, perkembangan tidak dapat dibedakan dari kemajuan pada setiap tahap dan bisa jauh lebih baik daripada sebelumnya. Untuk menjadi orang tua dan keluarga yang dapat memperhatikan tumbuh kembang anaknya, orang tua perlu memahami pentingnya keterlibatan orang tua dalam tumbuh kembang anaknya dalam konsep perkembangan (Hasiana, 2020).

Mereka membantu peneliti mengevaluasi teknik stimulasi, metode stimulasi, dan pelatihan yang dikembangkan untuk orang dewasa yang lebih tua. Penelitian Purvandri H (2011) menemukan bahwa dukungan keluarga sebagai stimulus atau stimulan tumbuh kembang bayi dapat mempercepat tumbuh kembang bayi pada kelompok intervensi. Bayi dan anak membutuhkan stimulasi yang baik. Masa kanak-kanak adalah masa emas, tetapi mengarah pada perkembangan. Dengan tidak adanya stimulasi, sosialisasi, berbicara, dan keterampilan motorik halus yang tidak konsisten menjadi tertunda (Anandika \& Hidayat, 2015).

Pertumbuhan dan perkembangan seorang anak sangat dipengaruhi tidak hanya oleh keluarga, tetapi juga oleh ayah, ibu dan anggota keluarga lainnya. Menurut beberapa guru, anak-anak sangat dekat dengan perkembangan baik di lingkungan fisik maupun tradisional. Setiap orang di lingkungan anak memegang peranan yang sangat penting dalam psikologi perkembangan anak. Jika seorang bayi dilahirkan dalam lingkungan yang kondusif, maka pertumbuhan berpengaruh besar terhadap pertumbuhan hingga periode berikutnya, begitu pula sebaliknya (E. Suprayitno et al., 2020).

Melakukan stimulasi yang memadai artinya merangsang otak balita sehingga perkembangan balita dapat tercapai secara optimal disesuaikan dengan umur anak sehingga dqapat mencegah penyimpangan tumbuh kembang. Alternatif yang tepat untuk mengatasi adanya penyimpangan tumbuh kembang pada anak balita dengan melakukan intervensi dini dengan mengadakan deteksi dini pada usia balita secara berkesinambungan (Khasanah et al., 2019). Kegiatan pendampingan dapat menambah pengetahuan seseorang (Emdat Suprayitno \& Wahid, 2019).

\section{KESIMPULAN DAN SARAN}

Pengetahuan keluarga tentang tumbuh kembang anak dan pencegahan pencegahan penularan Covid-19 meningkat setelah dilakukan pendampingan peran keluarga terhadap tumbuh kembang anak selama masa pandemic Covid-19. Pendampingan Peran Keluarga Terhadap Tumbuh Kembang Anak Di Masa Pandemi Covid-19 Di Ra Al Hilal Pamolokan Berjalan dengan baik dan terlaksana sesuai dengan tujuan dan rencana. klegiatan ini juga mendapat sembutan yang baik dari kepala sekolah ,guru dan masyarakat setempat dimana banyak keluarga menghadiria penyeluhan tersebut kegiatan pemyeluruhan kesehatan tersebut berdampak positif bagi keluarga yang meiliki anak usia sekolah untuk selalu memantau perkembangan anaknya.

Perlu meningkatakan fungsi kontroling dalam memantau dan mengetahui tumbuh kembang anaknya. Serta basi sekolah sebagai media informasi tentang manfaat dari melaksanakan peran keluarga dalam memantau perkembangan anaknya.

\section{UCAPAN TERIMA KASIH}

Ucapan terimakasih kami berikan kepada kepala sekolah Ra Al Hilal Pamolokan yang memberikan ijin PKM dan terimakasih kepada para orang tua yang telah bersedia mengikuti kegiatan PKM. 


\section{DAFTAR PUSTAKA}

Anandika, W. W., \& Hidayat, A. (2015). Pengaruh Penyuluhan terhadap Perilaku Stimulasi Tumbuh Kembang pada Ibu di PAUD Tapak Dara Bangunjiwo Kasihan Bantul. STIKES'Aisyiyah Yogyakarta.

De Figueiredo, C. S., Sandre, P. C., Portugal, L. C. L., Mázala-de-Oliveira, T., da Silva Chagas, L., Raony, Í., Ferreira, E. S., Giestal-de-Araujo, E., Dos Santos, A. A., \& Bomfim, P. O.-S. (2021). COVID-19 pandemic impact on children and adolescents' mental health: Biological, environmental, and social factors. Progress in Neuro-Psychopharmacology and Biological Psychiatry, 106, 110171.

Fatoni, A. F., Tanjungsari, T., \& Suprayitno, E. (2021). Bahasa Inggris Di Masa Pandemi: Kendala Pembelajaran Di Sdn Aengdake I. Jurnal Pendidikan Dasar, 1(1), 15-22.

Hasiana, I. (2020). Peran Keluarga dalam Pengendalian Perilaku Emosional pada Anak Usia 5-6 Tahun. Child Education Journal, 2(1), 24-33.

Hermoyo, P. (2015). Membentuk komunikasi yang efektif pada masa perkembangan anak usia dini. Pedagogi: Jurnal Anak Usia Dini Dan Pendidikan Anak Usia Dini, l(1).

Khasanah, U., Badriyah, B., Rahardjo, S., Nurlaili, A., \& Hendriyani, F. (2019). Pendampingan Deteksi Dini Tumbuh Kembang Anak Dengan Menggunakan Sdidtk Pada Guru Paud Dan Tk Di Kecamatan Socah Kabupaten Bangkalan. Community Development Journal, 3(1), 27-32.

Kurniyati, E. M., Setiawati, A. C., Suprayitno, E., \& Indriyani, R. (2021). Sari Kacang Hijau Dan Madu Meningkatkan Nilai Hemoglobin Remaja Kelas XI: Green and Honey Bean Sari Increases Hemoglobin Value of Class XI Adolescents. Jurnal Ilmiah Kebidanan (Scientific Journal of Midwifery), 7(1), 12-18.

Lefa, B. (2014). The Piaget theory of cognitive development: an educational implications. Educational Psychology, 1(9), 1-8.

Permatasari, D., \& Suprayitno, E. (2020). Implementasi Kegiatan Pendidik Sebaya dan Konselor Sebaya dalam Upaya Pencegahan Triad KRR di Pusat Informasi dan Konseling Remaja. Jurnal Ners Dan Kebidanan (Journal of Ners and Midwifery), 7(1), 143-150.

Puspitasari, D. I., Suprayitno, E., \& Bustami, B. (2021). Tingkat Stres Kerja Perawat Instalasi Gawat Darurat pada Masa Pandemi Covid-19. Wiraraja Medika: Jurnal Kesehatan, 11(1), 25-29.

Sugeng, H. M., Tarigan, R., \& Sari, N. M. (2019). Gambaran Tumbuh Kembang Anak pada Periode Emas Usia 0-24 Bulan di Posyandu Wilayah Kecamatan Jatinangor. Jurnal Sistem Kesehatan, 4(3). 
Supinganto, A., Pramana, C., Sirait, L. I., Kumalasari, M. L. F., Hadi, M. I., Ernawati, K., Staryo, N. A., Suprayitno, E., Utami, K., \& Hadi, S. P. I. (2021). The Use of Masks, as an Effective Method in Preventing the Transmission of the COVID-19, During Pandemic and the New Normal Era: A Review. Kusniyati and Hadi, Selasih Putri Isnawati, The Use of Masks, as an Effective Method in Preventing the Transmission of the COVID-19, During Pandemic and the New Normal Era: A Review (February 7, 2021).

Suprayitno, E., Purnomo, J. D. T., Sutikno, S., \& Indriyani, R. (2020). Health education in principle of community affected teenagaer's smooking attitude and habitual in the coastal area of madura island indonesia. International Journal of Psychosocial Rehabilitation, 24(10). https://doi.org/10.37200/IJPR/V24I10/PR300173

Suprayitno, Emdat, \& Huzaimah, N. (2020). Pendampingan lansia dalam pencegahan komplikasi hipertensi. SELAPARANG Jurnal Pengabdian Masyarakat Berkemajuan, 4(1), 518-521.

Suprayitno, Emdat, Rahmawati, S., Ragayasa, A., \& Pratama, M. Y. (2020). Pengetahuan dan Sikap Masyarakat dalam Pencegahan COVID-19. Journal of Health Science (Jurnal Ilmu Kesehatan), 5(2), 68-73.

Suprayitno, Emdat, \& Wahid, A. (2019). Pendampingan Tentang Penyakit Hipertensi Dan Perawatan Keluarga Dengan Hipertensi. Seminar Nasional Hasil Pengabdian Kepada Masyarakat, 3(1), 104-106.

Suryanto, S., Purwandari, H., \& Mulyono, W. A. (2014). Dukungan keluarga dan sosial dalam pertumbuhan dan perkembangan personal sosial, bahasa dan motorik pada balita di kabupaten Banyumas. KEMAS: Jurnal Kesehatan Masyarakat, 10(1), 103-109.

Tatminingsih, S. (2019). Alternatif Stimulasi Kemampuan Kognitif melalui Penerapan Model Pembelajaran Berbasis Permainan Komprehensif. Jurnal Obsesi: Jurnal Pendidikan Anak Usia Dini, 3(1), 183-190.

Ulfa, M. (2020). Peran Keluarga dalam Konsep Psikologi Perkembangan Anak Usia Dini. Aulad: Journal on Early Childhood, 3(1), 20-28. 